\title{
Analysis of success of vaginal birth after cesarean in relation to indication of primary caesarean section: a tertiary care experience
}

\author{
Neha Gupta*, Arpita De, Nidhi Gupta
}

Department of Obstetrics and Gynecology, Hamdard Institute of Medical Sciences and Research, Jamia Hamdard, New Delhi, India

Received: 19 July 2019

Accepted: 30 September 2019

\section{*Correspondence:}

Dr. Neha Gupta,

E-mail: docnehanigam@gmail.com

Copyright: (c) the author(s), publisher and licensee Medip Academy. This is an open-access article distributed under the terms of the Creative Commons Attribution Non-Commercial License, which permits unrestricted non-commercial use, distribution, and reproduction in any medium, provided the original work is properly cited.

\begin{abstract}
Background: Apprehensions related to vaginal birth after caesarean (VBAC) has reduced rates of successful vaginal trials over last decade. The objective of this study was to identify the indications of first caesarean section that can lead to a successful trial of labour in subsequent pregnancy.

Methods: Retrospective cohort study was done between November 2014 and October 2017. Data from the case records was analysed.

Results: Study over 3 years from 2014 to 2017 revealed fetal distress (82.7\%), breech (72.2\%), transverse lie $(66.7 \%)$, antepartum haemorrhage $(56.2 \%)$ and twins with first non-cephalic $(57.9 \%)$ have successful outcome of VBAC whereas obstructed labour $(19.2 \%)$ and failed induction $(18.4 \%)$ in previous pregnancy have poor outcome for VBAC.

Conclusions: Attempts to allow trial of labour after one previous caesarean section with fetal distress, malpresentation and twins as indications of caesarean in previous pregnancy are safe and should be encouraged.
\end{abstract}

Keywords: Caesarean section, Indication, Primary, Success, Trial of labour, Vaginal birth after cesarean

\section{INTRODUCTION}

Caesarean section rates have increased dramatically over last few decades. Once a caesarean, always a caesarean was a rule that was followed by most obstetricians. ${ }^{1}$ With increasing audits, evidence was produced that trial of labour was a safe and successful option in majority of such repeat pregnancies. ${ }^{2,3}$ Occasional uterine rupture and fetal risks have changed the outlook for trial of labour after previous caesarean section.,

Vaginal birth after cesarean (VBAC) has reduced in frequency over last 10 years. ${ }^{4-6}$ Elective repeat caesarean sections contribute in large proportion to the caesarean section rates. Gradually caesarean section rates are increasing in frequency. ${ }^{7,8}$ Reasons include better electronic monitoring and medico legal fears of a failed vaginal delivery and poor APGAR scores., ${ }^{9,10}$

Several studies published in Europe and India document this trend. Often, women who underwent a caesarean delivery after a prolonged labour in the first pregnancy do not want to undertake a trial of labour in this pregnancy. There is always a dilemma in obstetrician's mind about which patients are more likely to have a successful VBAC while counselling them for a trial of labor.

With this reducing trend of successful vaginal birth in patients with previous one caesarean section, younger obstetricians forego counselling the patients well for a 
trial of labour despite facility of adequate monitoring and emergency caesarean section being present.

This study was done to correlate success of trial of labour in subsequent pregnancy with indications for caesarean section in the first pregnancy.

The objective of this study was to identify the indications of first caesarean section that can lead to a successful trial of labour in subsequent pregnancy.

\section{METHODS}

This study is a retrospective cohort study carried out at a tertiary teaching hospital in Delhi. All previous one caesarean section deliveries over a 3-year period between November 2014 and October 2017 were studied and data was analysed.

\section{Inclusion criteria}

- Pregnancy with previous one caesarean delivery

- Singleton pregnancy

- Low transverse uterine scars.

\section{Exclusion criteria}

- Previous known classical or inverted ' $T$ ' uterine scar

- Previous hysterotomy/myomectomy entering uterine cavity

- Previous uterine rupture

- Presence of any contraindication to labour in current pregnancy such as placenta previa, malpresentation or cephalopelvic disproportion

- Refusal for trial of labor

- Incomplete records

- Non-viable pregnancy with term <26 weeks.

The above-mentioned case files were reviewed and a preformed proforma was filled. Note was made of the indications for primary caesarean section, course of labour, mode of delivery, success or failure of trial, maternal complications during delivery and neonatal ICU admissions.

\section{Statistical analysis}

Inference was drawn from this data after doing a statistical analysis between successful and failed trial of labour groups using Chi square test and $p$ value was calculated to make recommendations.

\section{RESULTS}

This study was carried out in Hamdard Institute of Medical Sciences and Research, New Delhi between November 2014 and October 2017.
There were four thousand four hundred and nine deliveries during the study period. There were three thousand and twenty-eight vaginal deliveries including instrumental deliveries during this period $(68.6 \%)$. There were five hundred and forty-seven deliveries with previous caesarean section. One hundred and eighteen patients were excluded from the study as they were taken up for elective caesarean section. Indications for elective caesarean section is as per Table 1 .

Table 1: Indications for elective repeat caesarean section $(n=118)$.

\begin{tabular}{|lll|}
\hline Indication & Number & Percentage \\
\hline Prev. 2LSCS & 57 & 48.3 \\
\hline Cephalopelvic disproportion & 19 & 16.1 \\
\hline Breech & 8 & 6.7 \\
\hline Transverse lie & 5 & 4.2 \\
\hline Ante partum haemorrhage & 8 & 6.7 \\
\hline Twins & 4 & 3.3 \\
\hline Previous myomectomy & 1 & 0.84 \\
\hline Short interconception period & 8 & 6.7 \\
\hline $\begin{array}{l}\text { Gestational diabetes with } \\
\text { deranged doppler }\end{array}$ & 4 & 3.3 \\
\hline Preterm with eclampsia & 3 & 2.5 \\
\hline Cord prolapse & 1 & 0.84 \\
\hline Total & $\mathbf{1 1 8}$ & $\mathbf{1 0 0}$ \\
\hline
\end{tabular}

Four hundred and twenty-nine patients were included in our study for attempt at vaginal delivery. One hundred and thirty-four (134) patients did not consent to trial of vaginal birth and opted for elective caesarean section $(31.2 \%)$. Two hundred and ninety-five patients of previous one caesarean section underwent trial of labour. One hundred and thirty-six had a successful vaginal birth after previous caesarean section $(46.1 \%)$. One hundred and fifty-nine patients were taken up for repeat emergency caesarean section (53.9\%).

Table 2: Indications for emergency repeat caesarean section $(n=159)$.

\begin{tabular}{|lll|}
\hline Indications & $\begin{array}{l}\text { Number } \\
\text { of cases }\end{array}$ & Percentage \\
\hline Fetal distress & 74 & 46.54 \\
\hline $\begin{array}{l}\text { Scar tenderness and signs } \\
\text { of impending rupture }\end{array}$ & 52 & 32.7 \\
\hline Failed progress of labour & 21 & 13.2 \\
\hline Failed Induction of labour & 12 & 7.54 \\
\hline Total & $\mathbf{1 5 9}$ & $\mathbf{1 0 0}$ \\
\hline
\end{tabular}

Most common reason for repeat emergency caesarean section was fetal distress. Other reasons for emergency repeat caesarean section are as per Table 2 .

Most common indication for previous caesarean section resulting in successful vaginal delivery was again fetal 
distress. Other reasons for previous caesarean section resulting in successful vaginal delivery are as per Table 3.

The patients with indication of first caesarean section as fetal distress, breech, antepartum haemorrhage, transverse lie, twins with first non-cephalic presentation had their $\mathrm{p}$ values significant for successful VBAC. Those patients who had undergone previous caesareans for failed induction and obstructed labour had significant $\mathrm{p}$ value for failure of VBAC. However, patients with failure to progress and bad obstetrical history did not show significant results. No maternal mortality was recorded during the study period. Most common maternal morbidity was fever in both successful and failed VBAC groups. Other common morbidity noted in both groups were urinary tract infections and PPH. More cases with gaped episiotomy $(2.8 \%)$ and retained products of conception $(0.7 \%)$ were noted in successful VBAC groups. Blood transfusions were needed in more emergency caesarean group $(6.2 \%)$.

Table 3: Indication of Primary caesarean section in relation with outcome of trial of labour.

\begin{tabular}{|c|c|c|c|c|c|}
\hline $\begin{array}{l}\text { Indications for } \\
\text { previous caesarean } \\
\text { section }\end{array}$ & $\begin{array}{l}\text { Total VBAC } \\
\text { (Successful + } \\
\text { Failed) }\end{array}$ & $\begin{array}{l}\text { Successful } \\
\text { VBAC }\end{array}$ & Failed VBAC & $\begin{array}{l}\text { Chi square } \\
{\text { test }=\text { chi }^{\wedge} 2 \text { value }}^{(p \text { value) }}\end{array}$ & Interpretation \\
\hline Fetal distress & 52 & $43(82.7 \%)$ & $9(17.3 \%)$ & $55.1(\mathrm{p}<0.05)$ & $\begin{array}{l}\text { Significant for } \\
\text { success }\end{array}$ \\
\hline Failure to progress & 63 & $24(38.1 \%)$ & $39(61.9 \%)$ & $2.5(\mathrm{p}>0.05)$ & $\begin{array}{l}\text { No inference } \\
\text { drawn }\end{array}$ \\
\hline Breech & 18 & $13(72.2 \%)$ & $5(27.8 \%)$ & $27.2(\mathrm{p}<0.05)$ & $\begin{array}{l}\text { Significant for } \\
\text { success }\end{array}$ \\
\hline $\begin{array}{l}\text { Ante partum } \\
\text { haemorrhage }\end{array}$ & 16 & $9(56.2 \%)$ & $7(43.8 \%)$ & $4.02(\mathrm{p}<0.05)$ & $\begin{array}{l}\text { Significant for } \\
\text { success }\end{array}$ \\
\hline Transverse lie & 18 & $12(66.7 \%)$ & $6(33.3 \%)$ & $17.7(\mathrm{p}<0.05)$ & $\begin{array}{l}\text { Significant for } \\
\text { success }\end{array}$ \\
\hline Failed induction & 38 & $7(18.4 \%)$ & $31(81.6 \%)$ & $31.5(\mathrm{p}<0.05)$ & $\begin{array}{l}\text { Significant for } \\
\text { failure of VBAC }\end{array}$ \\
\hline $\begin{array}{l}\text { Twins with first non- } \\
\text { cephalic }\end{array}$ & 19 & $11(57.9 \%)$ & $8(42.1 \%)$ & $5.7(\mathrm{p}<0.05)$ & $\begin{array}{l}\text { Significant for } \\
\text { success }\end{array}$ \\
\hline $\begin{array}{l}\text { Bad obstetrical } \\
\text { history }\end{array}$ & 19 & $7(36.8 \%)$ & $12(63.2 \%)$ & $3.2(\mathrm{p}>0.05)$ & $\begin{array}{l}\text { No inference } \\
\text { drawn }\end{array}$ \\
\hline Obstructed labour & 52 & $10(19.2 \%)$ & $42(80.8 \%)$ & $29.3(\mathrm{p}<0.05)$ & $\begin{array}{l}\text { Significant for } \\
\text { failure of VBAC }\end{array}$ \\
\hline Total & 295 & $136(46.1 \%)$ & $159(53.9 \%)$ & & \\
\hline
\end{tabular}

The $\mathrm{p}$ value is significant when $<0.05$.

No neonatal mortality was recorded in the study period. Neonatal ICU admissions were needed in $10.2 \%$ of successful VBAC and $19 \%$ of neonates born after emergency caesarean section.

\section{DISCUSSION}

Vaginal birth after previous caesarean section is a disappearing art in today's institutions. Percentage of deliveries undergoing successful vaginal deliveries (VBAC) were much higher a decade back. ${ }^{4,5}$ This did result in more morbidity and mortality in both mother and neonate1.

With better monitoring and lesser appetite for risk taking, these numbers have reduced. Lesser number of successful vaginal deliveries (VBAC) are being reported. This also leads to better maternal and neonatal results., ${ }^{4,6}$
Such inference can risk a perception that vaginal trials after previous caesarean section can be omitted for a safer maternal and neonatal outcome.

However, based on above results, it is possible to have a good maternal and fetal outcome after vaginal trials for select indications. Good monitoring can make decision making easier and delivery experience safer for mother and neonate.

Trial of labour in patients with indication of previous caesarean section as fetal distress and abnormal presentations (like breech and transverse lie) are best indications for a successful outcome. Even twins and antepartum haemorrhage has a good outcome for a trial of labour. Better outcomes are possible as these indications may not exist in next pregnancy and hence a well-managed intra-partum monitoring will lead to a successful vaginal delivery. 
Obstructed labour is mostly related to faulty pelvis or a large foetus, which may be a reason for repeat emergency caesarean section even in the next pregnancy. Trial of labour can result in increased maternal and neonatal morbidity in these cases. Often patients who had a failed induction and obstructed labor in previous deliveries are apprehensive and may not be good candidates to undergo the trial of labor for VBAC. Failure to progress and bad obstetrical history are grey zones in which inference could not be drawn from our study. With these as reasons for previous caesarean individualization may be needed and help from senior faculty may be useful.

Trial of labour in cases of previous caesarean section need to be increased and study in Scandinavia having historical higher rates of VBAC reveal a need for imparting information to the patient from treating clinician about advantages of VBAC as a first alternative. ${ }^{11,12}$ Having knowledge of above mentioned factors that can result in successful VBAC can reduce fear in clinicians for attempting VBAC. ${ }^{13}$

\section{CONCLUSION}

Trial of labour after previous caesarean section can be safely and successfully tried in cases with fetal distress, twins, antepartum haemorrage and malpresentations as indications for previous caesarean section. Obstructed labour and failed induction are reasonable risk factors for an increased maternal and neonatal mortality and should only be attempted for a vaginal trial in the presence of good monitoring and senior surgeons.

Funding: No funding sources

Conflict of interest: None declared

Ethical approval: The study was approved by the Institutional Ethics Committee

\section{REFERENCES}

1. Cragin EB. Conservatism in obstetrics. NY Med J. 1916;104:1-3,

2. Simões R, Bernardo WM, Salomão AJ, Baracat EC; Federação Brasileira das Associações de Ginecologiae Obstetrícia (Febrasgo).; Associação Médica Brasileira (AMB). Birth route in case of cesarean section in a previous pregnancy. Rev Assoc Med Bras. 2015;61(3):196-202.

3. Balachandran L, Vaswani PR, Mogotlane R. Pregnancy outcome in women with previous one cesarean section. J Clin Diagn Res. 2014;8(2):99102.

4. Gupta N, De A, Batra S. VBAC: changes over last 10 years. J Obstret Gyne India. 2019;69(2):110-4.

5. Christmann-Schmid C, Raio L, Scheibner K, Müller M, Surbek D. Back to once a caesarean: always a caesarean? A trend analysis in Switzerland. Arch Gynecol Obstet. 2016;294(5):905-10.

6. Kyvernitakis I, Reichelt J, Kyvernitakis A, Misselwitz B, Hadji P, Schmidt S, et al. Trends of vaginal birth after cesarean delivery in Germany from 1990 to 2012: a population-based study. Z Geburtshilfe Neonatol. 2014;218(5):203-9.

7. Mylonas I, Friese K. Indications for and Risks of Elective Cesarean Section. Dtsch Arztebl Int. 2015;112(29-30):489-95.

8. Daniel CN, Singh S. Caesarean delivery: An experience from a tertiary institution in north western Nigeria Niger J Clin Pract. 2016;19(1):18-24.

9. Betrán AP, Ye J, Moller AB, Zhang J, Gülmezoglu $\mathrm{AM}$, Torloni MR. The increasing trend in caesarean section rates, global, regional and national estimates: 1990-2014. PLoS One. 2016;11(2):e0148343.

10. Prakash KC, Neupane S. Cesarean deliveries among Nepalese mothers: changes over time 2001-2011 and determinants. Arch Gynecol Obstet. 2014;289(2):421-7.

11. Nilsson C, van Limbeek E, Vehvilainen-Julkunen K, Lundgren I. Vaginal birth after Cesarean: views of women from countries with high VBAC rates. Qual Health Res. 2017;27(3):325.

12. Lundgren I, Smith V, Nilsson C, VehvilainenJulkunen K, Nicoletti J, Devane D, et al. pregnancy childbirth. clinician-centred interventions to increase vaginal birth after caesarean section (VBAC): a systematic review. BMC. 2015;15:16.

13. Lundgren I, Healy P, Carroll M, Begley C, Matterne A, Gross MM, et al. Clinicians' views of factors of importance for improving the rate of VBAC (vaginal birth after caesarean section): a study from countries with low VBAC rates. BMC Pregnancy Childbirth. 2016;16(1):350.

Cite this article as: Gupta N, De A, Gupta N. Analysis of success of vaginal birth after cesarean in relation to indication of primary caesarean section: a tertiary care experience. Int J Reprod Contracept Obstet Gynecol 2019;8:4440-3. 